\section{Dietary Standards}

$\mathrm{I}^{\mathrm{N}}$ December 1935, a Commission of Experts (Technical Commission) appointed by the Health Committee of the League of Nations issued its London Report on the "Physiological Bases of Nutrition" (see NatuRE, Feb. 1, p. 176). The publication of this report was followed by its communication for study to representative learned societies, social studies institutions and health administrations in various countries. Observations received from such sources indicated general approval of the purpose and content of the report. Several suggestions were made, however, regarding details which might deserve further consideration. These were examined at a further meeting of the Technical Commission at Geneva in June last, with the result that a revised edition of its report has now been published*.

The most noticeable changes in the new edition are those which amplify the previous sections dealing with the feeding of children. The general principles of infant feeding are dealt with in greater detail. Such topics are now included as the use of heated milk to prevent milk-borne infections, the methods of preventing nutritional anæmia and the special requirements of premature infants. Dietary schemes are now included for children in the age groups 5-7 years and 12-14 years as well as for those in the younger groups. Incidentally, the energy allowances for children in the age groups 1-2 years and 2-3 years have now been slightly raised. A further alteration of note concerns the energy allowances for adults. It may perhaps be remembered that in the original report an allowance of 2,400 calories a day was suggested for men and women alike, with supplements for muscular activity varying according to the severity of the work performed. In the revised edition, the basal allowance is the same, but the supplements are increased, so that for light work the new seale allows up to 75 calories per hour of work in place of 50 , for moderate work 75-100 calories in place of $50-100$, for hard work $150-300$ instead of $100-200$ and for very hard work 300 calories and upwards instead of 200 and upwards.

Certain general principles regarding the choosing of suitable dietaries are set forth in greater detail in the new edition. The modern conception of 'protective' foods is elaborated; the term is defined as including foods which are especially rich in thase nutrient principles (good protein, vitamins and minerals) in which the chief foods of any geographical area are deficient. Good protein might thus be a valuable protective food in an Asiatic diet but not in a Western diet where a scarcity of it is comparatively rare. Attention is directed to the value of lightly as opposed to heavily milled cereals as a source of iron and vitamin $\mathrm{B}_{\mathrm{I}}$, and to butter in preference to other common fats because of its richness in vitamin $A$. The consumption of excessive amounts of sugar is condemned for the reason that it tends to lessen the proportion of protective foods in the diet as a whole. Lastly, the Commission has added to its list of problems requiring serious study the investigation of the optimum amount of milk required by human beings at different ages.

" "Report on the Physiological Bases of Nutrition." Revised and amplifled at the meeting held at Geneva, June 4-8, 1936. Quarierly Bulletin of the Bealth Organisation, League of Nations, 5, 391 (London: George Allen and Unwin, Ltd., 1936).

\section{Educational Topics and Events}

CAmbridge.--The Vice-Chancellor gives notice that the professors of physiology (Sir Joseph Barcroft), social anthropology (Prof. T. C. Hodson) and zoology (Prof. J. Stanley Gardiner) are due to retire on September 30, 1937.

Prof. Th. Von Kármán, of the California Institute of Technology, has been appointed Rouse Ball lecturer for the year 1936-37.

The following have been approved for the degree of Sc.D. : W. L. Edge, of Trinity College, and Dr. R. G. W. Norrish, of Emmanuel College.

At Clare College, E. N. Willmer, of St. John's College, University lecturer in physiology, has been elected into an official fellowship.

At Newnham College, the Henry Sidgwick Memorial Lecture will be delivered on November 28 at 5 p.m. by Lord Rutherford. The subject of the lecture is "Modern Alchemy".

The Adams Prize is open to the competition of all persons who have at any time been admitted to a degree in the University. Women are also eligible. The subject proposed for the period 1937-38 is the distributional properties of functions of statistical variables.

London.-The following degrees have been eonferred: D.Sc. (Economies) on R. P. Tripathi, an internal student, of the London School of Economics ; D.Sc. on E. E. Jelley, an external student, and D.Sc. (Engineering) on R. W. Bailey, an external student.

Oxford.-W. D. Hambly, of Jesus College, has been granted the degree of D.Sc. for his work in social anthropology.

Dr. J. A. Douglas has been appointed deputy for the professor of geology during the vacancy.

THE bicentenary of the University of Göttingen will be celebrated in the last week of June 1937.

The International Congress on Technical Education which was to have been held in Rome on May 28-30 but was indefinitely postponed will take place there on December 28-30. The Congress is under the auspices of the Bureau international de l'enseigne. ment technique, 2 Place de la Bourse, Paris, from which further information can be obtained.

The following scholarships, which are tenable for three or four years, according to the length of the course at the university selected, will be offered by the Institution of Naval Architects for competition in 1937: Naval Architecture: Martell, £130 per annum; Trewent, £125 per annum; Denny, £75 per annum. Marine Engineering: Parsons, £150 per annum; Yarrow, $£ 100$ per annum; Denny, $£ 75$ per annum. Full particulars may be obtained from the Secretary of the Institution of Naval Architects, 2 Adam Street, Adelphi, London, W.C.2.

ADuls education offers to a community suffering from the lag of the social sciences behind the advance of the naturaland technological sciences and threatened by consequent social disorganization a potent remedial instrument. It has, to use a metaphor popularized by Sir Josiah Stamp a propos of the "impact of 